\title{
Floral resources and habitat affect the composition of hummingbirds at the local scale in tropical mountaintops
}

\author{
Rodrigues, $L C{ }^{a *}$ and Rodrigues, $M{ }^{a}$ \\ aLaboratório de Ornitologia, Departamento de Zoologia, Instituto de Ciências Biológicas - ICB, Universidade \\ Federal de Minas Gerais - UFMG, Av. Antônio Carlos, 6627, Pampulha, Caixa Postal 486, \\ CEP 31270-901, Belo Horizonte, MG, Brazil \\ *e-mail: licleia@yahoo.com.br
}

Received: May 2, 2013 - Accepted: October 11, 2013 - Distributed: March 31, 2015

(With 4 figures)

\begin{abstract}
Hummingbird communities tend to respond to variation in resources, having a positive relationship between abundance and diversity of food resources and the abundance and/or diversity of hummingbirds. Here we examined the influence of floral resource availability, as well as seasonality and type of habitat on the composition of hummingbird species. The study was carried out in two habitats of eastern Brazilian mountaintops. A gradient representative of the structure of hummingbird community, based on species composition, was obtained by the ordination of samples using the method of non-metric multidimensional scaling. The composition of hummingbird species was influenced by the type of habitat and floral resource availability, but not by seasonality. Hummingbird communities differ between habitats mainly due to the relative abundance of hummingbird species. The variation in composition of hummingbird species with the variation in floral resource availability may be related to differences in feeding habits of hummingbirds. Hummingbird species with the longest bills visited higher proportions of ornithophilous species, while hummingbirds with shorter bills visited higher proportions of non-ornithophilous species. The results demonstrate that at local-scale the composition of hummingbird species is affected by the type of habitat and floral resources availability, but not by seasonality.
\end{abstract}

Keywords: Brazil, hummingbirds, campos rupestres, habitat preference, seasonality, Serra do Cipó.

\section{Recursos florais e habitat influenciam a composição de espécies de beija-flores em escala local em área de montanha tropical}

\section{Resumo}

Comunidades de beija-flores tendem a responder a variação em recursos, havendo uma relação positiva entre a abundância e diversidade de recurso alimentar com a abundância e/ou diversidade de beija-flores. Neste estudo nós analisamos a influencia da disponibilidade de recurso floral, bem como da sazonalidade e do tipo de habitat na composição de espécies de beija-flores. O estudo foi realizado em dois habitas de montanha do leste do Brasil. Um gradiente representativo da estrutura da comunidade de beija-flores, baseado na composição de espécies, foi obtido através da ordenação das amostras usando o método de escalonamento multidimensional não-métrico. A composição de espécies de beija-flores foi influenciada pelo tipo de habitat e disponibilidade de recurso floral, mas não pela sazonalidade. As comunidades de beija-flores variaram entre os habitas, principalmente devido a abundância relativa das espécies de beija-flores. A variação na composição de espécies de beija-flores com a variação na disponibilidade de recurso floral parece estar relacionada a diferenças nos hábitos alimentares dos beija-flores. Espécies de beija-flores com bicos de comprimentos maiores visitaram maiores proporções de espécies ornitófilas, enquanto beija-flores com bicos de comprimento menores visitaram maiores proporções de espécies não-ornitófilas. Os resultados demonstram que em escala local a composição de espécies de beija-flores é afetada pelo tipo de habitat e a disponibilidade de recurso floral, mas não pela sazonalidade.

Palavras-chave: Brasil, beija-flores, campos rupestres, preferência de habitat, sazonalidade, Serra do Cipó.

\section{Introduction}

In bird communities the species richness and abundance of individuals may vary spatially and temporally (Malizia, 2001) due to population processes (births and deaths) and individual movements within and between habitats (Loiselle and Blake, 1991; Poulin et al., 1993). The main reasons for movement are related to variation in resource availability, habitat structure, climates conditions and competition (Montgomerie and Gass, 1981; Wiens, 1989; Malizia, 
2001). However, food resources are the most important feature that affects the distribution pattern of many birds (Levey, 1988; Loiselle and Blake, 1991; Malizia, 2001). For many species, the capture rates of frugivorous birds have been positively correlated with fruit availability (Loiselle and Blake, 1991).

Hummingbirds are very mobile birds (Hadley and Betts, 2009) highly dependent on nectar and have high energy requirements (Diamond et al., 1986). Thus, the availability of flowers may lead the movements of hummingbirds within and between habitats in search of these resources (Montgomerie and Gass, 1981).

Moreover, the diversity and composition of hummingbird species may vary between biomes due to changes in climate conditions, as well as precipitation and temperature (Abrahamczyk and Kessler, 2010). Locally, hummingbird community tends to respond to changes in resource availability. It has been found a positive relationship between abundance and/or diversity of food resources and abundance and/or diversity of hummingbirds (Feinsinger, 1976; Des Granges, 1979; Montgomerie and Gass, 1981; Stiles, 1985; Malizia, 2001; Cotton, 2007). However, except for the study of Montgomerie and Gass (1981), who verified that the number of hummingbirds is positively correlated with daily energy available, measured from the daily nectar production per flower, no study so far verified the influence of energy availability of floral resources, as well as rainfall and the type of vegetation on the composition of hummingbird species.

We aim to test the hypothesis that hummingbird species composition varies according to floral resource availability among habitats and season in the open mountaintops of southeastern Brazil. We describe the seasonal variation of the hummingbird species richness and composition in two different habitats ('typical campos rupestres' or open rocky fields, and 'capões de mata' or forest patches) and its correlation to floral energetic resources.

\section{Methods}

\subsection{Study site}

This study was conducted in a region known as Alto do Palácio (hereafter AP, $19^{\circ} 15^{\prime} \mathrm{S}$ and $43^{\circ} 31^{\prime} \mathrm{W}$, at approximately $1350 \mathrm{~m}$ above sea level), which is located in the northern part of the Serra do Cipó National Park, southeastern Brazil (Rodrigues et al., 2011).

The AP region is characterized by campos rupestres habitats. In this region, the landscape is a mosaic consisting of the following characteristics: (1) typical campos rupestres or open rocky fields, which are areas of rocky outcrops with herbaceous vegetation and shrubs; (2) open grasslands composed predominantly of herbaceous species; and (3) capões de mata or forest patches, which are small areas of dense forest-like vegetation associated to wetter areas, such as springs and small streams (Rodrigues and Rodrigues, 2011).

The region experiences extreme variations in rainfall, with particularly wet summers (from November to January) and extremely dry winters (from June to September). Usually, there is a soil water deficit from May to August, which coincides with the coldest months of the year (hereafter referred to as the dry season). In the rainy season, which lasts from November to March, there is excess water in the soil coinciding with the warmest months of the year (Rodrigues et al., 2011).

\subsection{Data collection}

Data were collected monthly from August 2007 to July 2009 (except in December 2008, due to constant rain) in campaigns that lasted four to six days each.

To perform monthly assessments of the hummingbird species composition and richness in an open rocky field and two forest patches, 10 mist nets $(12 \times 2.6 \mathrm{~m}, 25-\mathrm{mm}$ mesh) were mounted during two sampling events (one morning for each habitat).

The mist nets were mounted at sunrise (0600 h EST), remained open for six consecutive hours and were checked every $30 \mathrm{~min}$. The captured hummingbirds were identified and banded. To record the species that were not captured in the mist nets and to record the hummingbirds' visits to flowers, observations were performed during the early morning along transects of $1800 \mathrm{~m}$ of trails with $1200 \mathrm{~m}$ in the open grassland and $600 \mathrm{~m}$ in the open rocky fields. Each 5-min observation was performed at 100-m intervals. In the forest patches walks were performed monthly in the surroundings of two forest patches (total areas of $230 \mathrm{~m}^{2}$ and $170 \mathrm{~m}^{2}$ ) with one 5-min observation point in each area. All of the hummingbirds spotted during the walk and at the observation points were recorded (modified from Feinsinger, 1976).

The hummingbirds were categorised as resident if they were registered throughout the year (even when they were not registered for up to two consecutive months) and as non-resident if they were absent for three or more consecutive months (modified from Machado, 2009).

The plant species visited by the hummingbirds were recorded by direct observation or with the aid of binoculars while walking along the transects. In addition, we conducted monthly focal observations (with minimal and maximum durations of $40 \mathrm{~min}$ and $180 \mathrm{~min}$, respectively) on species selected based on the following characteristics: 1) flowering species used by hummingbirds or 2) species that produced nectar and whose morphology allowed visitation by these birds (Rodrigues and Araujo, 2011). We prioritised flowering plants that were more easily accessed, had a greater abundance of flowers and were close to other flowering plants that could also be visited (Rocca-de-Andrade, 2006). The observations were done in different hours of anthesis, mainly between $0600 \mathrm{~h}$ and $1100 \mathrm{~h}$ and between $1500 \mathrm{~h}$ and $1800 \mathrm{~h}$.

The quantity of floral resources available to hummingbirds was recorded monthly at the same trails where the sightings were performed. The number of flowers on all flowering individuals along the trails and in a 10-m wide strip in the open rocky field (resulting in a total of $6000 \mathrm{~m}^{2}$ ) was recorded. In the two forest patches, sampling was 
performed using systematic walks at the edge and in the interior to sample the entire area of this environment $\left(400 \mathrm{~m}^{2}\right)$ (Rodrigues and Rodrigues, 2014).

To quantify the volume and concentration of nectar, we bagged flower buds and flowers (in the case of flowers that last more than one day) and measured between 1000 and $1300 \mathrm{~h}$ of the following day. The nectar volume was measured using a microsyringe, and the concentration of solutes was measured with a manual refractometer (Atago, 0-32\%; Galetto and Bernardello, 2005). The ideal sampling size consisted of 20 flowers of at least three different individuals; however, limitations intrinsic to each species (such as the density of individuals in the study area and/ or plants that only produce a single flower every two or three days) resulted in varied sample sizes. To estimate the energetic value of the nectar, the nectar volume and concentration measurements were converted to $\mathrm{mg}$ of total sugar according to Galetto and Bernardello (2005). The data of nectar volume, concentration and mg of total sugar were present in Rodrigues and Rodrigues (2014).

The resource density (RD) of ornithophilous and non-ornithophilous resources available each month for the hummingbirds in each of the sample areas was calculated by the following Equation 1:

$$
R D=\sum\left(F_{x} \cdot N_{x}\right) / \mathrm{A}
$$

where $\mathrm{F}=$ total number of open flowers per day; $\mathrm{N}=$ average total quantity of $\mathrm{mg}$ of sugar in the nectar; $\mathrm{x}=$ visited plant; and $\mathrm{A}=$ size of the sampled area $\left(\mathrm{m}^{2}\right)$ in each of the studied habitats.

The in situ total precipitation was measured monthly using a pluviometer located near the sampled areas (Rodrigues and Rodrigues 2014).

\subsection{Data analysis}

Hummingbirds with evident sexual dimorphism were treated separately in the analyses (Rodrigues and Araujo, 2011; Rodrigues and Rodrigues, 2011). Months in which fewer than three hummingbirds were recorded and hummingbird species that occurred in less than three months in the two habitats were excluded from the ordination and from the non-metric multidimensional scaling (NMDS) analysis.

The quantity of floral resources available for the hummingbirds was represented by the proportion of ornithophilous resources (which is inversely proportional to that of non-ornithophilous resources) calculated monthly for each of the environments based on the resource density. Pearson correlation analyses were performed to verify whether there was a relationship between the ornithophilous and non-ornithophilous resource density and precipitation.

A representative gradient of the hummingbird community structure based on species composition was obtained by sample ordination. These ordinations were obtained from matrices on the relative abundance of species (Ferreira, 1997). The Bray-Curtis dissimilarity index (Bray and Curtis, 1957) was used to obtain the association matrices that were subsequently subjected to NMDS. The proportion of explained variance (" $R$ ") of the values of the original distances in the association matrix relative to those derived from the ordination in one, two and three dimensions was used to decide the number of dimensions of the ordinations (e.g., Azevedo-Ramos et al., 1999). Based on the comparison of the $R^{2}$ values, an ordination with three dimensions was selected.

The effect of the variables "habitat", "quantity of available floral resource", "precipitation" and "sampling period (month)" on the hummingbird species composition in the sampled environments was tested by multivariate analysis of covariance (Pillai trace statistic). The analyses were performed using R 2.9.1 software (R Development Core Team, 2009).

\section{Results}

We recorded 12 hummingbird species during the study period. With the exception of Heliomaster squamosus (Temminck, 1823), male Thalurania glaucopis (Gmelin, 1788) and female Thalurania sp., which were found only in the forests patches, all other species recorded in this study occurred in both of the studied habitats (Chart 1).

In the two sampled habitats, 195 individuals of hummingbirds belonging to 11 species were captured and marked. We captured 114 individuals in the open rocky fields and 81 individuals in the forest patches. Augastes scutatus (Temminck, 1824), was the species with the largest number of captures $(\mathrm{N}=107$; males $=66$, females $=33$ and 3 individuals of indeterminate sex), being 76 individuals captured in the open rocky fields (males $=46$ and females $=27$ ) and 31 in the forest patches (males $=20$ and females $=11$ ). Amazilia versicolor (Vieillot, 1818) and Leucochloris albicollis (Vieillot, 1818) were the species with the smallest number $(\mathrm{N}=2$ for each species) of captures (Figure 1). With the exception of male and female of A. scutatus (Figure 2A and B) and Campylopterus largipennis (Boddaert, 1783) (Figure 2C), which were more frequently captured in the open rocky fields, the other hummingbirds were more frequently observed in the forest patches or had similar frequencies between the sampled habitats (Figure 1). Three hummingbird species were recorded throughout approximately the entire study period and considered as resident, namely, A. scutatus, Colibri serrirostris (Vieillot, 1816) (Figure 2D) and Phaethornis pretrei (Lesson \& Delattre, 1839) (Chart 1 and Figure 2F).

The variation in the hummingbird species composition in both habitats was represented by the NMDS ordination in three dimensions $\left(R^{2}=0.89\right)$. The hummingbird community differed between the sampled habitats $(\mathrm{p}<0.01$, Table 1), mainly due to the relative abundance of males of A. scutatus, which were negatively correlated with the first dimension of the NMDS ordination $(r=-0.96$, Table 2). Males of Augastes scutatus were more abundant in the open rocky fields than in the forest patches throughout the study period (Figure 3). Phaethornis pretrei was also important in separating the open rocky fields and 
Chart 1. Hummingbird species recorded throughout the first study year (August 2007 to July 2008, dotted lines) and the second year (August 2008 to July 2009, continuous lines) in the forest patches and the open rocky field at Alto do Palácio, Serra do Cipó National Park.

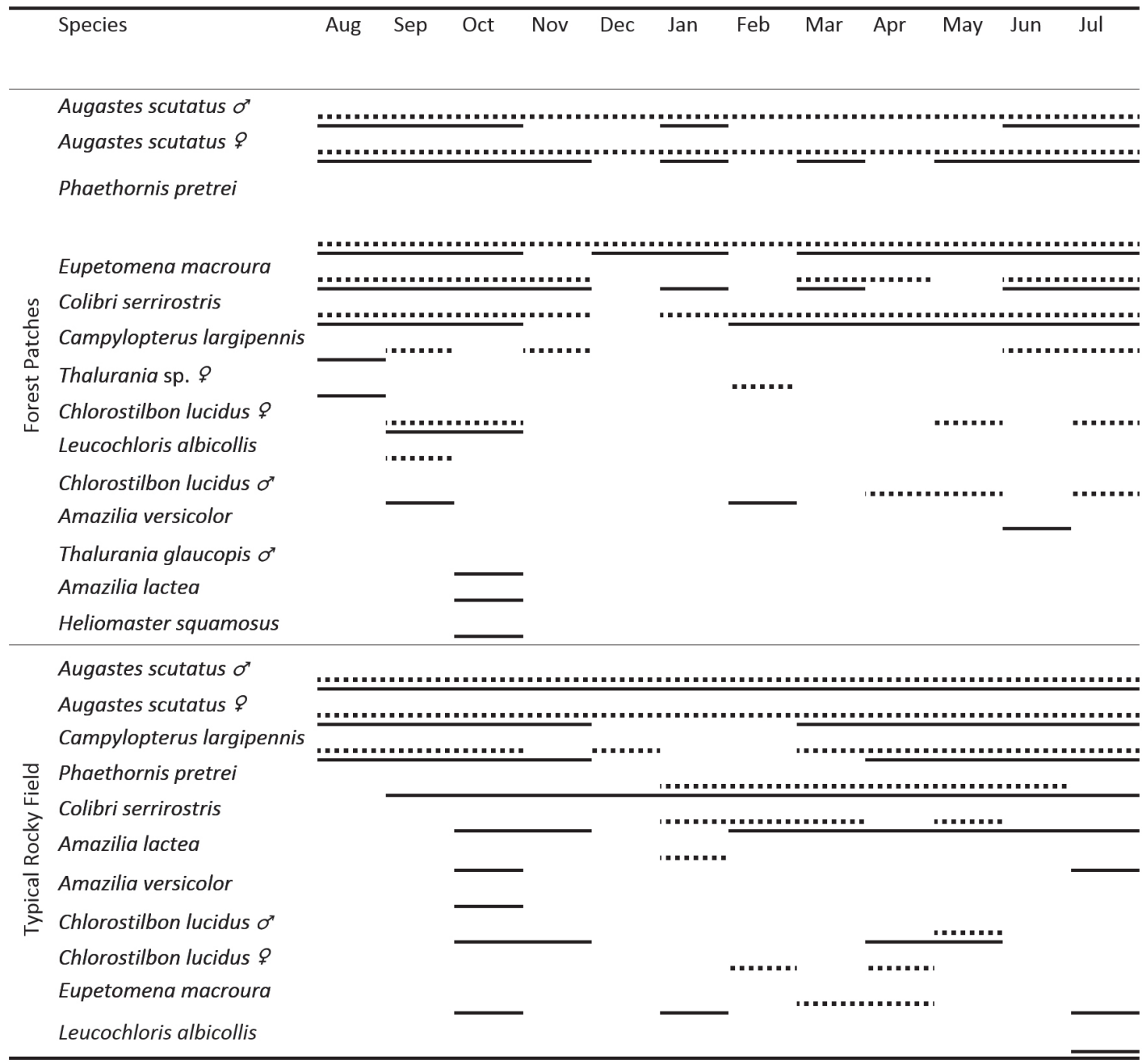

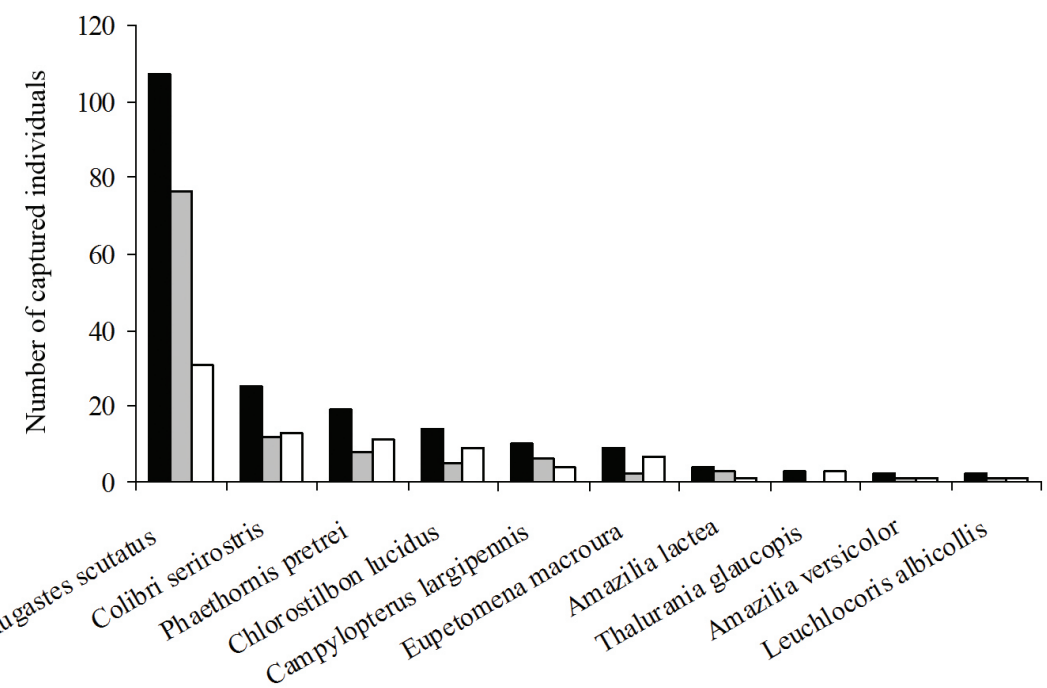

Figure 1. Total number (black bars) of captured hummingbirds per species and the number of hummingbirds captured in the open rocky field (grey bars) and forest patches (empty bars) at Alto do Palácio, Serra do Cipó National Park. 

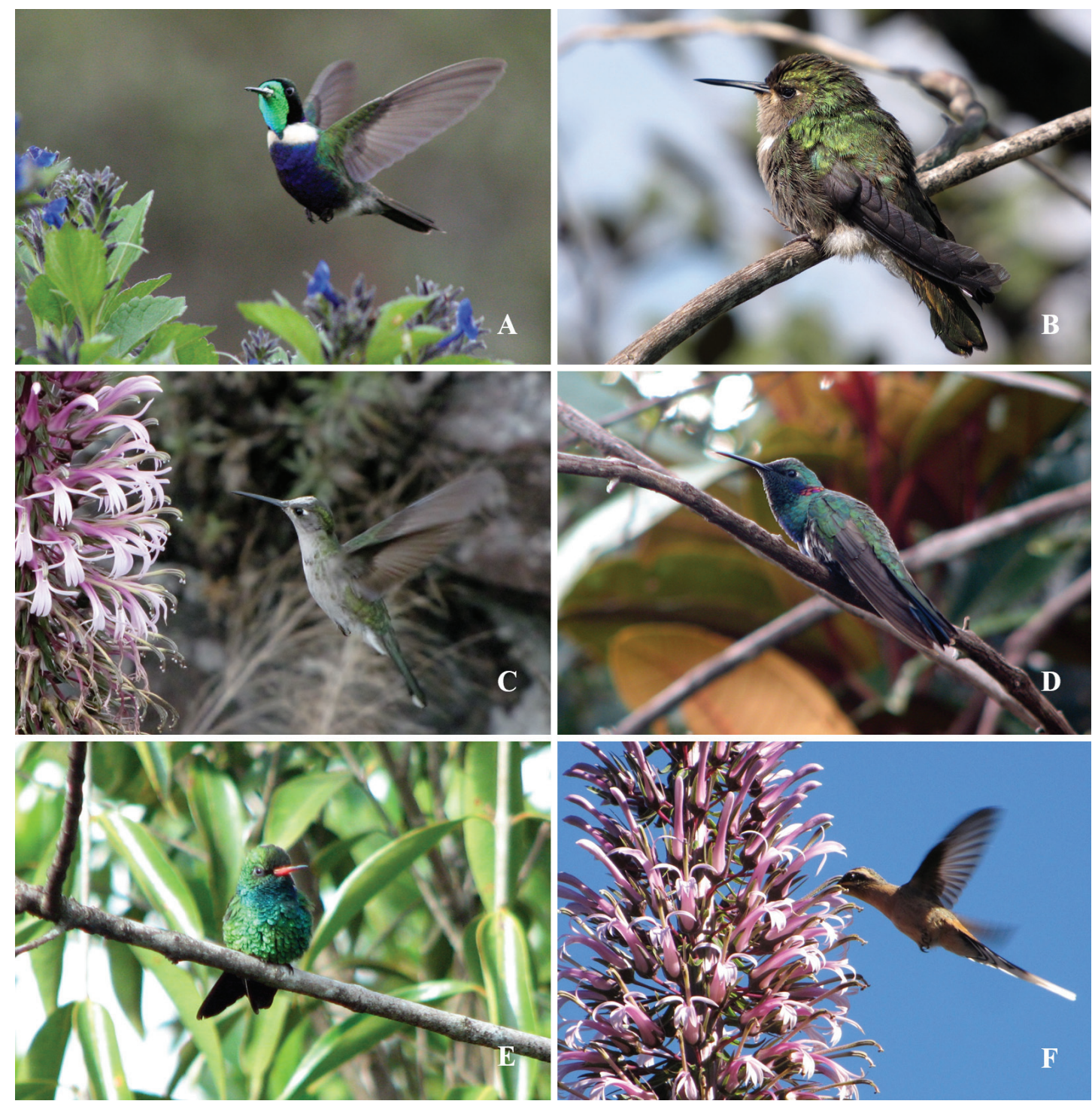

Figure 2. Hummingbird species recorded at Alto do Palácio, Serra do Cipó National Park, MG. A, male Augastes scutatus (photo: Guilherme Freitas); B, female Augastes scutatus; C, Campylopterus largipennis; D, Colibri serrirostris; E, male Chlorostilbon lucidus and F, Phaethornis pretrei visiting Lobelia fistulosa, an ornithophilous species with a long corolla.

Table 1. Results of the multivariate covariance analysis ( $\mathrm{df}=3$ and 31$)$ used to explain the variation in the hummingbird species composition during 22 sample months in a typical rocky field and in forest patches, at Alto do Palácio, Serra do Cipó National Park. The species composition was represented by sample ordination in three dimensions using non-metric multidimensional scaling.

\begin{tabular}{lccr}
\hline \multicolumn{1}{c}{ Source of variation } & Pillai trace & F & P \\
\hline Study period (month) & 0.21 & 2.82 & 0.06 \\
Phytophysiognomy & 0.34 & 5.21 & $<0.01$ \\
Precipitation & 0.08 & 0.94 & 0.43 \\
Ornithophilous resource & 0.23 & 3.15 & 0.04 \\
\hline
\end{tabular}

forest patches samples (Table 2); in addition, males of A. scutatus were abundant, whereas $P$. pretrei males were not. A similar pattern was found for females of $A$. scutatus and $C$. serrirostris (Figure 3); however, this pattern was related to the second dimension, which did not clearly distinguish between the habitats (Table 2). The remaining hummingbirds had little contribution $(r<0.5$, Table 2$)$ to the separation of the samples between the habitats.

For both habitats, the greatest number of hummingbird species $(\mathrm{N}=10)$ was recorded in October 2008 (Chart 1), 
Table 2. Correlations between the relative abundances of hummingbird species (separated by sex for species with evident sexual dimorphism) and the three dimensions of the sample ordination by non-metric multidimensional scaling. Absolute values greater than 0.5 are shown in bold.

\begin{tabular}{lccc}
\hline \multicolumn{1}{c}{ Hummingbird } & \multicolumn{1}{c}{ NMDS dimensions } \\
\cline { 2 - 4 } & $\mathbf{1}$ & $\mathbf{2}$ & $\mathbf{3}$ \\
\hline Augastes scutatus & -0.96 & -0.05 & -0.15 \\
Phaethornis pretrei & 0.58 & -0.09 & -0.74 \\
Augastes scutatus + & 0.27 & 0.85 & 0.16 \\
Colibri serrirostris & 0.32 & -0.75 & 0.40 \\
Eupetomena macroura & 0.49 & -0.28 & 0.16 \\
Chlorostilbon lucidus & 0.21 & 0.36 & 0.10 \\
Campylopterus largipennis & -0.19 & 0.01 & 0.09 \\
Chlorostilbon lucidus + & 0.10 & 0.29 & 0.23 \\
Amazilia lactea & 0.02 & -0.10 & 0.35 \\
\hline
\end{tabular}
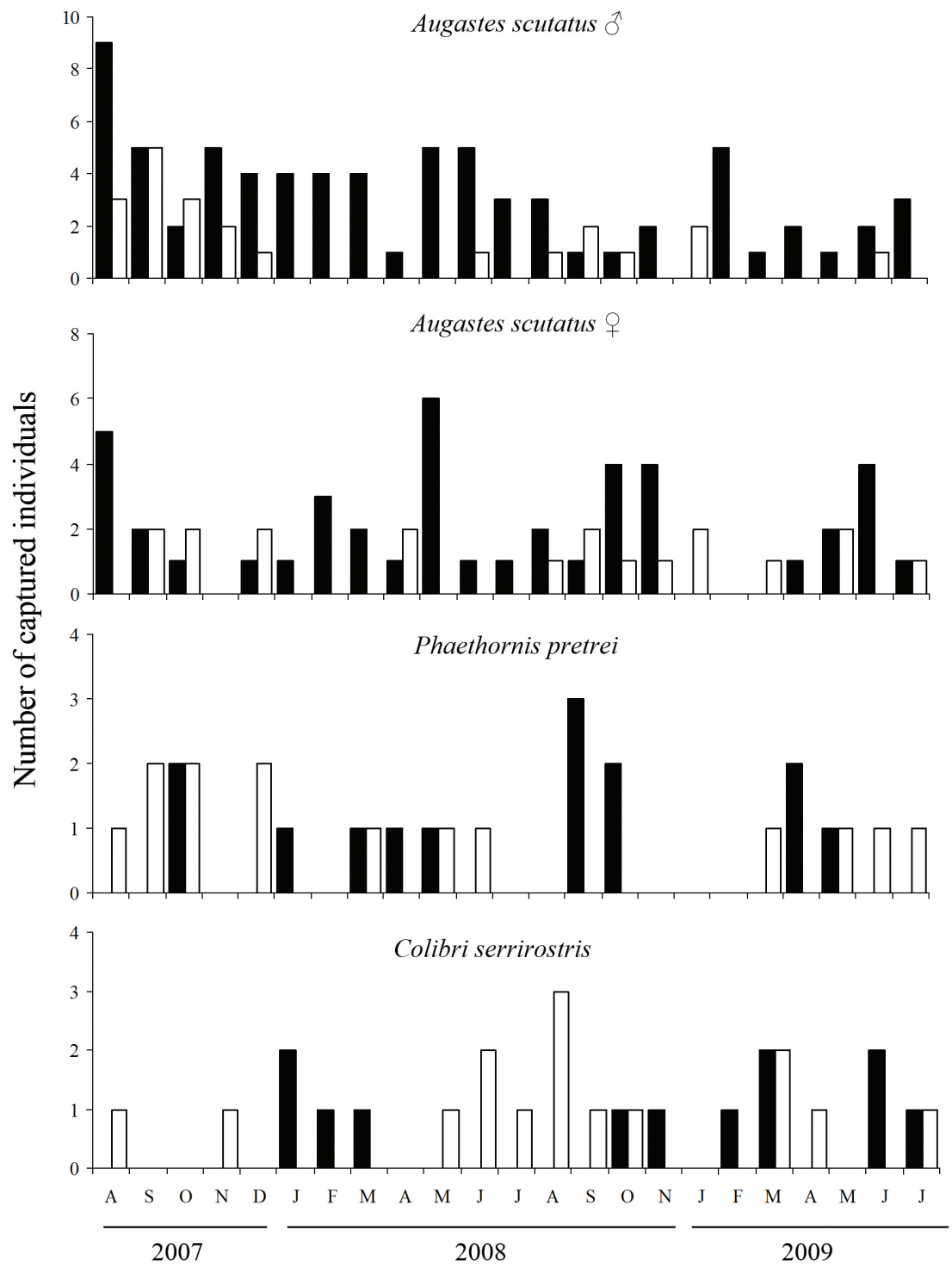

Figure 3. Number of captured individuals per month in the open rocky field (full bars) and in the forest patches (empty bars) for the most abundant species and that influenced the separation of the samples between the phytophysiognomies according to the NMDS. 
and the greatest number of captures occurred in August $(\mathrm{N}=22)$ and September $(\mathrm{N}=19) 2007$ and October 2008 $(\mathrm{N}=20)$, periods with a low precipitation (Figure 4). However, the hummingbird species composition did not vary significantly in correlation with either the sampling period or precipitation (Table 1).

Hummingbird visited 51 plant taxa when subspecies and varieties were considered separately, with $43 \%$ $(\mathrm{N}=22)$ and $57 \%(\mathrm{~N}=29)$ of these being ornithophilous and non-ornithophilous, respectively (see Rodrigues and Rodrigues, 2014). The open rocky fields area presented a greater number of visited species $(\mathrm{N}=38)$ when compared to the forest patches $(\mathrm{N}=17)$. The largest portion of these species were non-ornithophilous (open rocky fields $=58 \%$, forest patches $=53 \%$ ).

Male and female $A$. scutatus visited the largest number of plant species $(\mathrm{N}=29$ and $\mathrm{N}=20$, respectively), especially the non-ornithophilous species (males $=76 \%$ and females $=60 \%$ ), whereas $P$. pretrei visited the largest proportion of ornithophilous species ( $82 \%)$.

The density of ornithophilous resources was not correlated with precipitation $(\mathrm{p}=0.1$ in the open rocky fields and $p=0.09$ in the forest patches), and the same observation was made for the density of non-ornithophilous resources ( $p=0.78$ for open rocky fields, $p=0.21$ for forest patches) (Table 3). However, the proportion of ornithophilous resources explained a good proportion of the variation in the hummingbird species composition (Table 1); i.e., variations in the proportion of ornithophilous resources correspond to variations in the hummingbird species that occur in each sample.

\section{Discussion}

This is the first study to show that at a local scale, hummingbird species composition (species that comprise the samples and species relative abundance) is influenced by the type of habitat and the availability of floral resources but not the seasonality (precipitation and sampling period). The hummingbird community of the open rocky fields differs from that of the forest patches, mainly due to the relative abundance of the most common hummingbirds (males and females of $A$. scutatus, $C$. serrirostris and $P$. pretrei) in a given habitat of the Alto do Palácio region. This finding appears to reflect the habitat preferences of these species.

\subsection{Species richness and composition}

The recorded hummingbird species richness, as well as the number of resident hummingbird species, was higher than those observed in previous studies performed for at least one year with monthly sampling in natural forest patches in the Pantanal (Araujo and Sazima, 2003), in a cerrado area (Rodrigues and Araujo, 2011) and in open rocky fields areas (Vasconcelos and Lombardi, 1999; Machado et al., 2007). However, it was similar to the registered in certain Atlantic Forest areas (Araujo, 1996; Rocca-de-Andrade, 2006) and in the Colombian Amazon (Rosero-Lasprilla and Sazima, 2004).

Although the number of Phaethornitinae species was similar to values recorded in certain Atlantic Forest areas (Araujo, 1996; Rocca-de-Andrade, 2006), in the Colombian Amazon (Rosero-Lasprilla and Sazima, 2004) and in natural forest patches in the southern Pantanal (Araujo and Sazima, 2003), the hummingbird $P$. eurynome was recorded only in larger forest patches. Therefore, the presence of this hummingbird is associated to the presence of forested areas at Alto do Palácio, a typical environment for Phaethornitinae species (Stiles, 1981).

Augastes scutatus, the most abundant hummingbird and the one with the highest relative abundance in the open rocky fields (both males and females), is a species endemic to the Espinhaço Range. Its distribution is restricted to the central-southern portion of the range, and it occurs only at altitudes greater than $1000 \mathrm{~m}$ (Vasconcelos and Rodrigues, 2010). Augastes scutatus appears to be more dependent on plant species that occur in open rocky

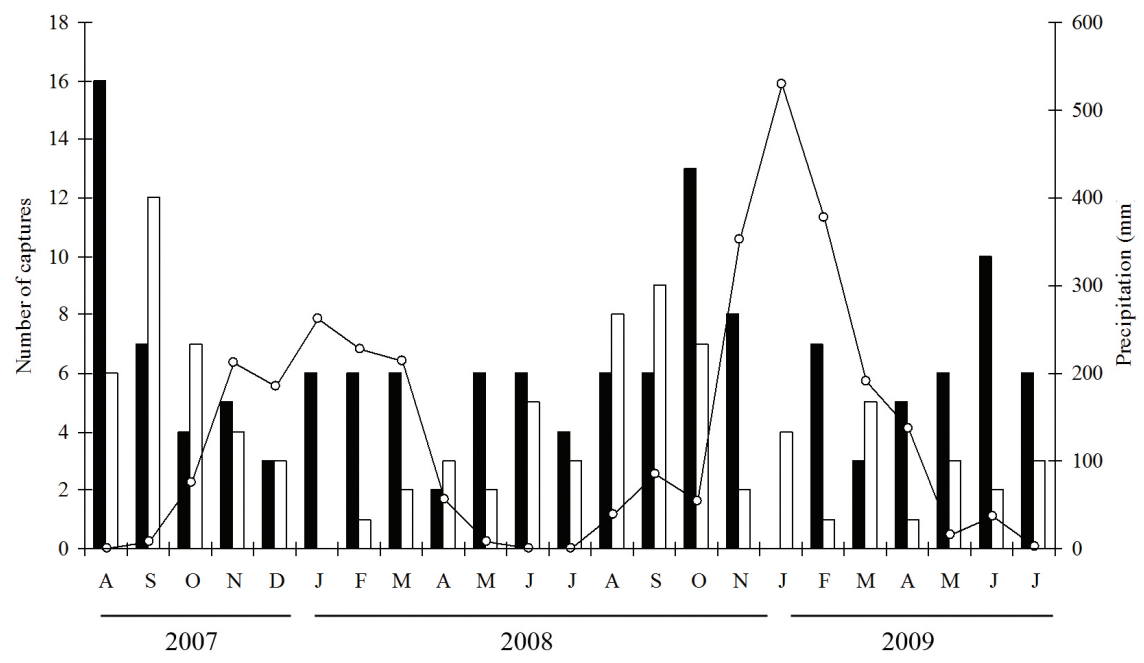

Figure 4. Precipitation (line) and number of hummingbird individuals captured throughout the study period in the open rocky field (black bars) and in the forest patches (empty bars) at Alto do Palácio, Serra do Cipó National Park. 
Table 3. Precipitation $(\mathrm{mm})$ and energy density $\left(\mathrm{mg}\right.$ of sugar $/ \mathrm{m}^{2}$ ) of ornithophilous and non-ornithophilous resources throughout the study period in the open rocky field (ORF) and in the forest patches (FP) at Alto do Palácio, Serra do Cipó National Park.

\begin{tabular}{|c|c|c|c|c|c|}
\hline \multirow{3}{*}{ Month } & \multirow{3}{*}{ Precipitation } & \multicolumn{4}{|c|}{ Resource density } \\
\hline & & \multicolumn{2}{|c|}{ Ornithophilous } & \multicolumn{2}{|c|}{ Non-ornithophilous } \\
\hline & & FP & ORF & FP & ORF \\
\hline Aug/07 & 0.00 & 0.036 & 0.000 & 3.455 & 1.733 \\
\hline Sept/07 & 7.25 & 0.000 & 0.004 & 0.000 & 0.035 \\
\hline Oct/07 & 74.75 & 0.000 & 0.001 & $<0.001$ & $<0.001$ \\
\hline Nov/07 & 212.50 & 0.000 & 0.060 & 0.000 & 0.024 \\
\hline Dec/07 & 185.25 & 0.035 & 0.038 & 0.000 & 0.011 \\
\hline Jan/08 & 261.25 & 0.139 & 0.018 & $<0.001$ & 0.047 \\
\hline $\mathrm{Feb} / 08$ & 227.00 & 0.030 & 0.022 & 0.000 & 0.030 \\
\hline Mar/08 & 213.25 & 0.100 & 0.078 & 0.004 & 0.001 \\
\hline Apr/08 & 56.00 & 0.003 & 0.077 & 0.020 & 0.021 \\
\hline May/08 & 8.00 & 0.001 & 0.010 & 0.004 & 0.007 \\
\hline June/08 & 0.00 & 0.001 & 0.046 & 0.000 & 0.003 \\
\hline July/08 & 0.00 & 0.152 & 0.015 & 0.769 & 0.010 \\
\hline Aug/08 & 39.00 & 0.031 & 0.022 & 0.014 & 0.969 \\
\hline Sept/08 & 84.00 & 0.015 & $<0.001$ & 4.037 & $<0.001$ \\
\hline Oct/08 & 53.75 & 0.046 & 0.004 & 0.981 & $<0.001$ \\
\hline Nov/08 & 352.50 & 0.087 & 0.047 & 0.000 & 0.007 \\
\hline $\mathrm{Feb} / 09$ & 377.15 & 0.151 & 0.039 & 0.000 & 0.035 \\
\hline Mar/09 & 190.75 & 0.174 & 0.057 & 0.003 & 0.016 \\
\hline Apr/09 & 136.75 & 0.058 & 0.029 & 0.000 & 0.010 \\
\hline May/09 & 15.25 & 0.069 & 0.026 & 0.000 & 0.023 \\
\hline June/09 & 36.70 & 0.010 & 0.146 & 0.000 & 0.013 \\
\hline July/09 & 2.50 & 0.002 & 0.032 & 0.000 & 0.013 \\
\hline
\end{tabular}

fields and becomes locally extinct in degraded areas, possibly because of the extinction of certain plant species (Vasconcelos and Lombardi, 1999). This hypothesis is supported by the present study, which recorded visits made by this hummingbird to 23 plant species that occur in the open rocky fields and only 11 species that occur in forest patches (see Rodrigues and Rodrigues, 2014). In addition, A. scutatus also appears to prefer open rocky fields as a nesting site (Rodrigues and Rodrigues, 2011). Therefore, this species may be considered highly adapted to open rocky fields, depending on its floral and nesting resources (Rodrigues et al., 2013).

Phaethornis pretrei was usually more abundant in the forest patches areas throughout the study period. The Phaethornitinae are generally more frequently observed in the understory of closed areas, such as riparian forests (Stiles, 1981; Cotton, 1998). In the Alto do Palácio region, . pretrei moves among the forest patches. Colibri serrirostris was also more abundant in the forest patches, which appears to be related to the territorial behaviour of this species. For nearly the entire study period (August and September 2007, January to August 2008 and January to July 2009), one vocalising $C$. serrirostris individual was observed on a perch in each of the sampled forest patch.
These individuals left these areas only for short periods ( 5 to $30 \mathrm{~min}$ ), most likely to forage in adjacent areas.

\subsection{Floral resource availability}

The hummingbird species compositions in the studied habitats varied due to the availability of floral resources, which is most likely related to the hummingbirds' ability to learn to locate areas with greater resource availability (Malizia, 2001; Altshuler and Nunn, 2001; Cole et al., 1982). An experimental study by Cole et al. (1982) showed that the learning of resource locations by hummingbirds is related to the spatial distribution of resources, which influences the energy acquisition rate. Therefore, during periods of low energetic availability within a habitat, individuals of these species may switch locally to another habitat or forage in nearby areas with greater resource availability, as has been reported for other hummingbird communities (Wolf et al., 1976; Montgomerie and Gass, 1981; Kodric-Brown et al., 1984; Stiles, 1985). In addition, the recorded hummingbird species used different floral resources, which reduces the competition among species (Stiles, 1985).

The hummingbirds with greater bill lengths used a larger proportion of ornithophilous resources in their diets and usually used flowers with greater corolla lengths. 
Conversely, hummingbirds with smaller bill lengths used a large proportions of non-ornithophilous species and generally used flowers with smaller corolla lengths (L.C. Rodrigues et al., unpublished data). Therefore, when the energetic availability of a given flower type is low within a habitat, the hummingbirds may search for the flower in another habitat or in nearby areas. In this way, hummingbird species composition varies with changes in the energy density of floral resources.

Certain studies have shown that the flowering peak of the species visited by hummingbirds is concentrated at the end of the dry season and/or during the entire rainy season (Arizmendi and Ornelas, 1990; Sazima et al., 1996; Araujo and Sazima, 2003). However, in this study, no correlation was found between the energy density of floral resources and precipitation. The constant availability of energy resources for hummingbirds most likely favours the residence of the three hummingbirds species that were the most abundant in the study area. In addition, the residence of these species may be one of the factors explaining the absence of a relationship of hummingbird species composition with precipitation and sampling period.

Although pronounced seasonality occurred in the study area, the hummingbird species compositions did not correlate with this factor (precipitation and sampling period). However, the compositions varied with the type of habitat, mainly due to the habitat preferences of the species that form the community as well as differences in the availability of ornithophilous and non-ornithophilous resources in the studied phytophysiognomies. The hummingbird species compositions also varied with the availability of floral resources, which is related to the hummingbirds' capacity to locate the floral resources, as well as their preferences for different flower types.

\section{Acknowledgements}

We are grateful to $\mathrm{CNPq}$ and Capes for a scholarship awarded to LCR. MR thanks CNPq (473428/2004-0 and 300731/2006-0) and FAPEMIG (PPM APQ-0434-5.03/07). M. L.M. Varela, D. F. Dias, F. C. Diniz and R. Rocha helped in fieldwork. The Chico Mendes Institute (ICMBio) and directors of the Serra do Cipó National Park for logistical support. A. C. Araujo, C. M. Jacobi, M. F. Vasconcelos and M. Araujo greatly improved the manuscript.

\section{References}

ABRAHAMCZYK, S. and KESSLER, M., 2010. Hummingbird diversity, food niche characters, and assemblage composition along a latitudinal precipitation gradient in the Bolivian lowlands. Journal für Ornithologie, vol. 151, no. 3, p. 615-625. http://dx.doi. org/10.1007/s10336-010-0496-x.

ALTSHULER, DL. and NUNN, AM., 2001. Observational Learning in Hummingbirds. The Auk, vol. 118, no. 3, p. 795-799. http:// dx.doi.org/10.1642/0004-8038(2001)118[0795:OLIH]2.0.CO;2.
ARAUJO, AC., 1996. Beija-flores e seus recursos florais numa área de planície costeira do litoral norte de São Paulo. Campinas: Universidade Estadual de Campinas. Dissertação de Mestrado.

ARAUJO, AC. and SAZIMA, M., 2003. The assemblage of flowers visited by hummingbirds in the capões of southern Pantanal, Mato Grosso do Sul, Brazil. Flora, vol. 198, no. 6, p. 427-435. http:// dx.doi.org/10.1078/0367-2530-00116.

ARIZMENDI, MC. and ORNELAS, JF., 1990. Hummingbirds and their floral resources in a tropical dry forest in Mexico. Biotropica, vol. 22, no. 2, p. 172-180. http://dx.doi.org/10.2307/2388410.

AZEVEDO-RAMOS, C., MAGNUSSON, WE. and BAYLISS, P., 1999. Predation as the key factor structuring tadpole assemblages in a savanna area in central Amazonia. Copeia, vol. 1999, no. 1, p. 22-33. http://dx.doi.org/10.2307/1447381.

BRAY, JR. and CURTIS, JT., 1957. An ordination of the upland forest communities of southern Wisconsin. Ecological Monographs, vol. 27, no. 4, p. 325-349. http://dx.doi.org/10.2307/1942268.

COLE, S., HAINSWORTH, FR., KAMIL, AC., MERCIER, T. and WOLF, LL., 1982. Spatial learning as an adaptation in hummingbirds. Science, vol. 217, no. 4560, p. 655-657. http:// dx.doi.org/10.1126/science.217.4560.655. PMid:17817537

COTTON, PA., 1998. The hummingbird community of a lowland Amazonian rainforest. The Ibis, vol. 140, no. 3, p. 512-521. http:// dx.doi.org/10.1111/j.1474-919X.1998.tb04613.x.

COTTON, PA., 2007. Seasonal resource tracking by Amazonian hummingbirds. The Ibis, vol. 149, no. 1, p. 135-142. http://dx.doi. org/10.1111/j.1474-919X.2006.00619.x.

DES GRANGES, JL., 1979. Organization of a tropical nectar feeding bird guild in a variable environment. Living Bird, vol. 17, p. 199-236

DIAMOND, JM., KARASOV, WH., PHAN, D. and CARPENTER, FL., 1986. Digestive physiology is a determinant of foraging bout frequency in hummingbirds. Nature, vol. 320, no. 6057, p. 62-63. http://dx.doi.org/10.1038/320062a0. PMid:3951548

FEINSINGER, P., 1976. Organization of a tropical guild of nectarivorous birds. Ecological Monographs, vol. 46, no. 3, p. 257-291. http://dx.doi.org/10.2307/1942255.

FERREIRA, AM., 1997. Transformações de dados em medidas de semelhança e suas interpretações ecológicas. Revista Brasileira de Ecologia, vol. 1, p. 111-114.

GALETTO, L. and BERNARDELLO, G., 2005. Rewards in flowers: Nectar. In DAFNI, A., Kevan, PG. and Husband, BC. (Eds.). Practical pollination biology. Cambridge: Enviroquest Ltd. 590 p.

HADLEY, AS. and BETTS, MG., 2009. Tropical deforestation alters hummingbird movement patterns. Biology Letters, vol. 5, no. 2, p. 207-210. http://dx.doi.org/10.1098/rsbl.2008.0691. PMid:19158031

KODRIC-BROWN, A., BROWN, JH., BYERS, GS. and GORI, DF., 1984. Organization of a tropical island community of hummingbirds and flowers. Ecology, vol. 65, no. 5, p. 1358-1368. http://dx.doi.org/10.2307/1939116.

LEVEY, DJ., 1988. Spatial and temporal variation in Costa Rican fruit and fruit-eating bird abundance. Ecological Monographs, vol. 58, no. 4, p. 251-269. http://dx.doi.org/10.2307/1942539. 
LOISELLE, BA. and BLAKE, JG., 1991. Temporal variation in birds and fruits along an elevational gradient in Costa Rica. Ecology, vol. 72, no. 1, p. 180-193. http://dx.doi.org/10.2307/1938913.

MACHADO, CG., COELHO, AG., SANTANA, CS. and RODRIGUES, M., 2007. Beija-flores e seus recursos florais em uma área de campo rupestre da Chapada Diamantina, Bahia. Revista Brasileira de Ornitologia, vol. 15, p. 267-279.

MACHADO, CG., 2009. Beija-flores (Aves: Trochilidae) e seus recursos florais em uma área de caatinga da Chapada Diamantina, Bahia, Brasil. Zoologia, vol. 26, no. 2, p. 255-265. http://dx.doi. org/10.1590/S1984-46702009000200008.

MALIZIA, LC., 2001. Seasonal fluctuations of birds, fruits, and flowers in a subtropical forest of Argentina. The Condor, vol. 103, no. 1, p. 45-61. http://dx.doi.org/10.1650/00105422(2001)103[0045:SFOBFA]2.0.CO;2.

MONTGOMERIE, RD. and GASS, CL., 1981. Energy limitation of hummingbird populations in tropical and temperate communities. Oecologia, vol. 50, no. 2, p. 162-165. http://dx.doi.org/10.1007/ BF00348031.

POULIN, B., LEFEBVRE, G. and MCNEIL, R., 1993. Variations in bird abundance in tropical arid and semiarid habitats. The Ibis, vol. 135 , no. 4 , p. 432-441. http://dx.doi.org/10.1111/j.1474919X.1993.tb02116.x.

R Development Core Team, 2009. R: A language and environment for statistical computing. Vienna: R Foundation for Statistical Computing. Available from: <http://www.R-project.org $>$.

ROCCA-DE-ANDRADE, M., 2006. Recurso floral para aves em uma comunidade de Mata Atlântica de encosta: sazonalidade e distribuição vertical. Campinas: Universidade Estadual de Campinas. Tese de Doutorado em Biologia Vegetal.

RODRIGUES, LC. and ARAUJO, AC., 2011. The hummingbird community and their floral resources in an urban forest remnant in Brazil. Revista Brasileira de Biologia = Brazilian Journal of Biology, vol. 71, no. 3, p. 611-622. PMid:21881784.

RODRIGUES, M., FREITAS, GHS., COSTA, LM., DIAS, DF., VARELA, MLM. and RODRIGUES, LC., 2011. Avifauna of Alto do Palácio, Serra do Cipó National Park, state of Minas Gerais, southeastern Brazil. Check List, vol. 7, p. 151-161.

RODRIGUES, LC. and RODRIGUES, M., 2011. Size dimorphism, juvenal plumage, and timing of breeding of the hyacinth Visorbearer (Augastes scutatus). The Wilson Journal of Ornithology, vol. 123 , no. 4, p. 726-733.
RODRIGUES, LC., MARTINS, FI. and RODRIGUES, M., 2013. Survival of a mountaintop hummingbird, the Hyacinth Visorbearer Augastes scutatus, in Southeastern Brazil. Acta Ornithologica, vol. 48, no. 2, p. 211-219. http://dx.doi.org/10.3161/000164513X678801

RODRIGUES, LC. and RODRIGUES, M., 2014. Flowers visited by hummingbirds in the open habitats of the southeastern Brazilian moutaintops: species composition and seasonality. Revista Brasileira de Biologia = Brazilian Journal of Biology, vol. 74, no. 3, p. 659-676. PMID: 252962.

ROSERO-LASPRILLA, L. and SAZIMA, M., 2004. Interacciones planta-colibrí em tres comunidades vegetales de la parte suroriental Del Parque Nacinal Natural Chiribiquete, Colombia. Ornitologia Neotropical, vol. 15, p. 183-190.

SAZIMA, I., BUZATO, S. and SAZIMA, M., 1996. An assemblage of hummingbird-pollinated flowers in a montane forest in southeastern Brazil. Botanica Acta, vol. 109, no. 2, p. 149-160. http://dx.doi.org/10.1111/j.1438-8677.1996.tb00555.x.

STILES, FG., 1981. Geographical aspects of bird-flower coevolution, with particular reference to Central America. Annals of the Missouri Botanical Garden, vol. 68, no. 2, p. 323-351. http://dx.doi.org/10.2307/2398801.

STILES, FG., 1985. Seasonal pattern and coevolution in the hummingbird-flower community of a Costa Rican sub-tropical forest. In BUCKLEY, PA., MORTON, MS., RIDGLEY, RS. and BUCKLEY, FG. (Eds.). Neotropical ornithology. Washington: American Ornithologists Union. p. 757-787.

VASCONCELOS, MF. and LOMBARDI, JA., 1999. Padrão Sazonal de ocorrência de seis espécies de beija-flores (Apodiformes: Trochilidae) em uma localidade de campo rupestre na Serra do Curral, Minas Gerais. Ararajuba, vol. 7, p. 71-79.

VASCONCELOS, MF. and RODRIGUES, M., 2010. Patterns of geographic distribution and conservation of the open-habitat avifauna of southeastern Brazilian mountaintops (campos rupestres and campos de altitude). Papéis Avulsos de Zoologia, vol. 50, p. 1-29.

WIENS, JA., 1989. A case study: interactions among nectarivores. In BARNES, RSK., BIRKS, HJB., CONNOR, EF. and PAINE, RT. (Eds.). The ecology of bird communities. Cambridge: Cambridge University Press. 316 p. Processes and variations, vol. 2.

WOLF, LL., STILES, FG. and HAINSWORTH, FR., 1976. Ecological organization of a tropical, highland hummingbird community. Journal of Animal Ecology, vol. 45, no. 2, p. 349379. http://dx.doi.org/10.2307/3879. 